\title{
REVIEW
}

\section{Gut size flexibility in rodents: what we know, and don't know, after a century of research}

\author{
Flexibilidad en el tamaño del tracto digestivo en roedores: qué sabemos, y qué no sabemos, \\ después de un siglo de investigación
}

\author{
DANIEL E. NAYA
}

\begin{abstract}
Center for Advanced Studies in Ecology \& Biodiversity, Pontificia Universidad Católica de Chile, Santiago 6513677, Chile
\end{abstract} e-mail for correspondence: dnaya@bio.puc.cl

\begin{abstract}
Phenotypic plasticity comprises a central concept in the understanding of how organisms interact with their environment, and thus, is a central topic in ecology and evolution. A particular case of phenotypic plasticity is phenotypic flexibility, which refers to reversible change in organism traits due to changes in internal or external environmental conditions. Flexibility of digestive features has been analyzed for more than a century in a myriad of different species and contexts. Studies in rodents on gut size flexibility have been developed mainly from two different areas of the biological sciences, physiology and ecology. However, as for several other topics related with physiological ecology, both kinds of studies largely developed along separate paths. Herein, I evaluate altogether the information belonging to both areas. The major conclusions reached are: (1) there is a clear match between digestive morphology adjustments and change in environmental conditions, and gut size flexibility could be considered a widespread physiological mechanism occurring in laboratory and wild species, and under laboratory, semi-natural and natural conditions. (2) For laboratory species, the experimental factors that have been more investigated are diet quality, reproductive status, environmental temperature and fasting, while for wild species the more analyzed factors are diet quality and temperature. (3) For wild rodent species, no differences in small intestine length flexibility between methodological approaches nor species feeding categories has been identified. (4) It appears that high energetic demands are mainly coped with by changes at the small intestine level, while changes in the amount of undigestible material in the diet are mainly coped with by changes in the hindgut. (5) Change in gut length may be related to a decrease in food retention time (e.g., during diet dilution), while change in gut mass appears to be related to a need of higher specific absorption (e.g., during highly demanding periods). (6) The qualities of an energetic demand (e.g., its relative intensity) rather than simply its presence or absence can affect the amount of digestive flexibility. (7) Quantitative comparisons of the existing data are difficult due to several factors, such as the disparity of experimental treatments and differences in the types of data collected. At the end of this review, further directions for the study of digestive flexibility in rodents are presented.
\end{abstract}

Key words: digestive physiology, phenotypic plasticity, physiological flexibility, rodents.

\section{RESUMEN}

La plasticidad fenotípica constituye un concepto medular en el entendimiento de cómo los organismos interactúan con su ambiente y, por tanto, un tema central en ecología y evolución. Un caso particular de la plasticidad fenotípica es la flexibilidad fenotípica, la cual refiere a los cambios reversibles en un organismo producto de cambios en las condiciones ambientales. La flexibilidad en los rasgos digestivos ha sido estudiada por más de un siglo en diversas especies y contextos. Para el caso de los roedores, los estudios sobre la flexibilidad en el tamaño del tracto digestivo han sido desarrollados principalmente desde dos áreas de la biología, la fisiología y la ecología. Sin embargo, como ha ocurrido con muchos tópicos relacionados con la fisiología ecológica, ambos tipos de estudios se desarrollaron por vías separadas. En este trabajo se intenta evaluar de forma conjunta la información proveniente de ambas áreas. Las principales conclusiones alcanzadas son: (1) la flexibilidad en el tamaño del tracto digestivo puede ser considerada un mecanismo fisiológico ampliamente distribuido, existiendo un clara congruencia entre los ajustes en la morfología digestiva y los cambios en las condiciones ambientales. (2) Los factores experimentales más investigados han 
sido la calidad de la dieta, el estatus reproductivo, la temperatura ambiental y el ayuno para las especies de laboratorio y la calidad de la dieta y la temperatura para las especies salvajes. (3) En especies salvajes no se han encontrado diferencias en la flexibilidad del largo intestinal entre estudios con distintas aproximaciones metodológicas ni entre especies con distintos hábitos tróficos. (4) Los cambios en la demanda energética parecen ser principalmente afrontados mediante ajustes en el intestino delgado, mientras que los cambios en la cantidad de material indigestible en la dieta parecen ser principalmente afrontados mediante ajustes en el ciego e intestino grueso. (5) Los cambios en el largo del tracto digestivo parecen estar relacionados con la necesidad de ajustar el tiempo de retención del alimento (e.g., durante la dilución de la dieta), mientras que cambios en la masa del tracto parecen estar relacionados con la necesidad de modificar la tasa de absorción específica (e.g., durante un periodo de alta demanda energética). (6) Las características de una demanda energética (e.g., su intensidad relativa), más que su simple presencia o ausencia, pueden afectar la magnitud de los ajustes en las dimensiones del tracto digestivo. (7) A pesar de la gran cantidad de trabajos publicados, comparaciones cuantitativas de los datos existentes son difíciles de realizar, debido a factores tales como la disparidad en los tratamientos experimentales y en el tipo de información reportada. Para finalizar esta revisión se presentan nuevas direcciones en cuanto al estudio de la flexibilidad digestiva en roedores.

Palabras clave: fisiología digestiva, plasticidad fenotípica, flexibilidad fisiológica, roedores.

\section{INTRODUCTION}

Phenotypic flexibility refers to reversible modifications in organism traits due to changes in environmental conditions (Piersma \& Drent 2003). In the last two decades, different lines of evidence -e.g., the correlation between different phenotypes (products of flexibility) and fitness (Pigliucci \& Schmitt 1999, Agrawal 2001), and the fact that flexibility is able to respond to both artificial and natural selection (Scheiner \& Lyman 1991, Scheiner 1993, Scheiner 2002)- suggest that phenotypic flexibility is adaptive. Thus, although usually not easily demonstrable by direct manipulation (Dudly et al. 1996, Schmitt et al. 1999), reversible phenotypic adjustments to changing conditions are hypothesized to increase organism fitness.

The flexibility of the digestive system has been analyzed for more than a century in a myriad of different vertebrate species and contexts (for reviews see Karasov \& Diamond 1983, Piersma \& Lindstrom 1997, Starck 1999, McWilliams \& Karasov 2001, Naya \& Bozinovic 2004, Naya et al. 2007). There are two characteristics of this system that generate a high degree of interest in the study of flexibility. First, the gut represents the functional link between food intake and metabolizable energy, i.e., the energy available to meet all vital functions (Karasov 1990, Wunder 1992, Secor 2001). Second, the digestive tract comprises one of the more expensive tissues of the body (McBride \& Kelly 1990, Cant et al. 1996), and thus, adjusting gut size to its functional demands could represent an important energy saving mechanism.

Studies on gut size flexibility in rodents have been mainly developed from two different areas of the biological sciences, physiology and ecology. However, as for several other topics in physiological ecology, both kinds of studies largely developed along separate paths during the last century (Spicer \& Gaston 1999). Studies coming from the physiological ground -here defined as those experimental studies conducted with laboratory species- started with the beginning of the $20^{\text {th }}$ century, increased during the 1950's, and then the number of studies per year remained fairly constant until the present. In contrast, ecological studies on wild rodents were mainly conducted from the second half of 1980's to the present. This increased interest in digestive flexibility of wild species during the last twenty years is related to two facts. On one hand, optimal digestion models (Sibly 1981, Penry \& Jumars 1987) provided a clear theoretical framework to interpret digestive adjustments as a response to changing environmental conditions. On the other hand, during the last two decades there also occurred a progressive recognition of some attributes of rodents that made them an attractive model to study digestive flexibility (Demment \& Van Soest 1985, Hume 1989, Folley \& Cork 1992, Justice \& Smith 1992, Wunder 1992). First, in general terms, rodents have high mass-specific metabolic rates (due to their small body size), and thus, energy-saving mechanisms have a great value in these species. Second, the way by which food intake rate and gut volume scale with body mass 
(approximately 0.75 and 1.0 , respectively) determine that a potential buffer capacity of the gut, to cope with changes in food intake, decreases with body size; hence, gut size adjustments should be more relevant in small sized species. Third, many rodent species occur in highly variable environments, and consume poor quality diets and (or) diets which quality markedly change between seasons.

The main goal of the present review is to evaluate altogether the evidence on rodent gut size flexibility derived from both physiological and ecological grounds, in order to synthesize the major findings achieved in this research area during the last century. Also, I try to identify the principal gaps in the current knowledge and to propose further directions for the study of digestive flexibility in rodents. I focused on digestive flexibility at the level of gut gross morphology (i.e., digestive organs length and mass), because changes in digestive capacity in response to changing intake level is mainly achieved by reversible changes in these features (Karasov \& McWilliams 2005).

\section{THE PHYSIOLOGICAL LITERATURE}

\section{The effect of diet bulkiness}

Roux (1906) probably was the first author that studied gut size flexibility in rodents. According to him, a concentrated diet, rich in easily digestible substances, was capable of stimulating the growth of the small intestine, thereby enabling a greater and more rapid digestion and absorption of the food (cited in Wierda 1950). During the first decades of the $20^{\text {th }}$ century, other authors analyzed the effect of diet bulkiness on gut morphology (e.g., Kestner 1929, Addis 1932). These studies found that diets with high content of undigestible material caused an increase in stomach and cecum size, but did not affect the dimension of the small intestine. However, few years later, Wierda (1942, 1950) designed much more controlled experiments in terms of experimental animals and diets, and showed that, although the effect of a diet with high content of undigestible material (30\% agar) was noticeable at the level of the hindgut, the small intestine was also able to respond to changes in diet quality. Moreover, when a non- fermentable substance (talc) was used as the bulky material, it was observed that the small intestine exhibited a proportionally greater increase in mass compared with the other digestive chambers (Friedman et al. 1953).

From these early works to the present, the study of diet bulkiness on gut size adjustments included the evaluation of several substances, such as cellulose and arabinose (Fischer 1957a), cellobiose (Fischer \& Lee 1958), kaolin (Dowling et al. 1967), potato starch (Fischer 1957a, El-Harith et al. 1976), pectin (Brown et al. 1979, Ikegami et al. 1990), guar gum (Poksay \& Schneeman 1983, Johnson \& Gee 1986, Ikegami et al. 1990), gum xanthan (Ikegami et al. 1990), glucomannan (Tokunaga et al. 1986) and non-soluble polysaccharides from raw peas (Goodlad \& Mathers 1990), soybean (Levrat et al. 1991), wheat bran and oat bran (Hansen et al. 1992). Because most of the latter studies used a fermentable substance as the bulky material, the observed increase in gut size was mainly due to an increment in the dimension of the cecum and colon (i.e., the fermentative chambers). In this sense, it is known that short chain fatty acids, generated during fermentation process, increased daily epithelial cell production three- (colon) to fourfold (jejunum) in the intestine of rats (Sakata 1987).

\section{The effect of diet compounds}

The analysis of specific dietary compound on gut size began with the work of Ershoff \& Deuel (1944), who observed a marked dilatation of the cecum in a diet with high content of lactose. Subsequently, several papers were published on the effect of diet chemistry on gut morphology. Specifically, Jessie Fisher and co-workers conducted a series of experiments, during the late 1950 , to evaluate the effect of diets with different contents of glucose, sucrose and lactose, (Lawrence et al. 1956, Fischer 1957a, 1957b, Fischer \& Lee 1958, 1959). These papers clearly showed that adjustment in the mass of digestive organs occurs in parallel with changes in diet composition, and the authors suggested that gut size modifications may have an adaptive value. At the same time, Morgan \& Yudkin (1957) studied the effect of saturated versus unsaturated fats in the diet on digestive 
morphology. These authors pointed out that animals consuming a diet with saturated fatty acids increased the volume of food ingested, which in turn cause a rise in gut size (i.e., a bulkiness effect). However, they noted that a significant part of the differences is played by the composition of the diet, since changes in gut size also occurred in animals on the diet containing unsaturated fatty acids, where the amount of food ingested was practically equal to the controls. In a similar way, it was observed that the amount of protein in the diet can affect gut size, and a decrease in the size of the small intestine mass occurred in parallel to dietary protein content (Hill et al. 1968).

\section{The effect of fasting}

Jackson (1915) studied the effect of acute and chronic inanition on the weight of several internal organs in the rat. This work showed that a reduction in the weight of the digestive tract, from about $6.0 \%$ of the body weight in normally feed rats to a $3.3 \%$ (in the acute fasted trial) or $3.5 \%$ (in the chronic fasted trial), occurs during inanition. Accordingly, Jackson concluded that the alimentary canal, together with the liver, lose weight much more heavily than the whole body, and therefore a decrease in absolute and relative weight it is observed. Several years later, these results were confirmed by other authors who demonstrated that the liver and the digestive tract comprise the organs that contribute the most to protein catabolism during fasting (e.g., Addis et al. 1936, Thaysen \& Thaysen 1949, Ju \& Nasset 1959). In addition, Ju \& Nasset (1959) reported that a recovery of nitrogen content occurs 96 hours after feeding and that this recuperation was more rapid and complete in the small intestine than in other organs.

From the above mentioned works to the present, several studies investigated the mechanistic basis for the changes in gut size during fasting periods (e.g., Brown et al. 1963, Steiner et al. 1968, Levine et al. 1974, McNurlan et al. 1979, Goodman \& Fleck 1980, Burrin et al. 1988, Dunel-Erb et al. 2001, see also Carey 1990, 1992, Carey \& Cook 1991, Carey \& Martin 1996 for data on Spermophilus tridecemlineatus). Although a detailed analysis of the evidence for these mechanisms is beyond the scope of the present review, it should be noted that adjustments in both, cell size and cell number, are part of the overall response (for a recent review see Wang et al. 2006).

\section{The effect of reproductive state}

Abramson (1934) evaluated organ size changes that occur during pregnancy, and observed that the small intestine size began to increase from the first half of pregnancy, while the stomach increased only during the second half of this period. Five years latter, the changes in weight and protein concentration of different organs that occurs during pregnancy and lactation were analyzed again (Poo et al. 1939). Now, it was found that the organs where greater concentration of proteins occurs were the liver (mainly during the pregnancy) and the digestive tract (mainly during the lactation). After these two pioneering works, many other authors reported data on the effect of pregnancy and lactation on gut size (e.g., Souders \& Morgan 1957, Fell et al. 1963, Campbell \& Fell 1964, Peters et al. 1967, Craft 1970, Sigdestad \& Osborne 1972, Cripps \& Williams 1975, Mainoya 1978, Cañas et al. 1982). All these studies found a marked increase in the size of the small intestine during lactation (see Peters et al. 1967 for the only exception), but only a minor enlargement during pregnancy. In addition, these studies indicated that: (i) the adjustment in gut length occurs at a slower rate than that in gut mass, and digestive size changes are reversible (Cripps \& Williams 1975), (ii) the increase in whole-animal metabolism observed during lactation is mainly due to an increase in weights of organs with high maintenance energy expenditures (i.e., intestine, liver and heart), although a rise in specific metabolic activity of different tissues also occurs (Cañas et al. 1982).

On the other hand, it should be noted that lactation in mice comprised a key model for the study of limitation to animal energetic budgets (Bacigalupe \& Bozinovic 2002, Speakman \& Krol 2005). Consequently, many studies conducted within this context during the last ten years provide data on gut adjustments during lactation. From the perspective of gut size flexibility, the reported data are very similar to those discussed in the previous paragraph: the size of the small intestine increased during pregnancy, and this increase is even greater 
during lactation (Hammond \& Diamond 1992, Speakman \& McQueenie 1996). In addition, studies that evaluated lactation at different temperatures reported an additional increase in the mass of the small intestine in lactating females exposed to cold environments (Hammond et al. 1994, Krol et al. 2003).

\section{The effect of environmental temperature}

The first studies that evaluated the effect of environmental temperature on gut size were conducted in the context of the study of animal adaptations to the cold. At the end of the 1950's, Herox and co-workers acclimated rats to 6 and $30{ }^{\circ} \mathrm{C}$ and found an increase in the small intestine mass at lower temperatures (Heroux \& Gridgeman 1958, Heroux \& Campbell 1959). Indeed, it was observed that digestive tract changes occurred in both outdoor and indoor conditions, though it was less noticeable in the former situation. In the same vein, Barnett \& Widdowson (1965) studied the adjustments that occur in mice exposed to cold for from days to many generations. It was found that an increase in small intestine size occurs in a cold environment, but this change did not augment beyond the first generation. After that, Musacchia \& Barr (1969) reported an increase in the mass of the intestine at lower temperatures in the golden hamster (Mesocricetus aureatus). In the recent years, several authors have evaluated the effect of low environmental temperatures on the digestive tract, mainly in the context of energy budget limitation debate (Toloza et al. 1991, Konarzewski \& Diamond 1994, McDevitt \& Speakman 1994, Stalinski 1994). Again, the obtained results did not differ from those discussed above: higher energy demands due to low environmental temperatures determine an increase in gut size, mainly at the level of the small intestine.

\section{The effect of combined energy demands}

Barnett \& Widdowson (1971) compared data on pregnancy and lactation at two temperatures, with previous data from virgin females also acclimated to warm and cold conditions (Barnett \& Widdowson 1965). The main result of these works was that the small intestine mass was shown to increase rather linearly from virgin females reared at $21{ }^{\circ} \mathrm{C}$ to lactating females reared at $-3{ }^{\circ} \mathrm{C}$, suggesting an additive effect of both demanding factors. More recently, two studies that analyzed the combined effect of temperature and diet quality indicated that although both factors are able to affect the small intestine mass and length, there was no interaction between them (Zhao et al. 1995, 1996). In the last years, Deborah Kristan and Kimberly Hammond evaluated the combined effect of parasitism and dietary caloric restriction (Kristan \& Hammond 2001), parasitism and lactation (Kristan 2002, Kristan \& Hammond 2004), parasitism and cold temperatures (Kristan \& Hammond 2000, 2003), and parasitism, dietary caloric restriction and cold temperatures in mice (Kristan \& Hammond 2006). The main result of these works is that depending on the type of demands that are combined, multiple demands will elicit responses that are either independent of each other (e.g., parasitism and lactation, or parasitism and temperature) or interact with each other (e.g., parasitism and caloric restriction).

\section{Other physiological studies}

There are other factors that determine change in the size of digestive organs, but data are too scarce to allow general conclusions. These included intermittent starvation (e.g., Holeckova \& Fabry 1959, Fabry \& Kujalova 1960, Holeckova 1964), hypothalamic lessons (e.g., Brobeck et al. 1943), acetylphenylydrazine administration (e.g., Conrad et al. 1965), germfree rats (e.g., Goodlad et al. 1988), intestinal resection (e.g., Booth et al. 1959, Hammond et al. 1996b), diabetes (e.g., Jervis \& Levin 1966), thyrotoxicosis (e.g., Levin \& Smith 1963), growth hormone (Leblond \& Carriere 1955), T4 hormone (e.g., Derting \& Bogue 1993), sorbitol (Morgan \& Yudkin 1957), polyethylene glycol (Loeschke et al. 1973), and chlortetracycline (Lee \& Fisher 1958).

\section{THE ECOLOGICAL LITERATURE}

\section{Evidences from the field}

Interestingly, the first work that reported data on gut variation for animals collected in the 
field was conducted in rats. Heroux (1961) observed that the enlargement of the digestive tract, recorded in indoor cold-acclimated white rats was lower than those observed in outdoor cold-acclimated animals. Then, he captured specimens from the field and compared their gut size flexibility against white rats reared in indoor and outdoor conditions. He found that, unlike cold-acclimated rats, field winter animals did not show an enlargement of the gut, and he explained the result by a combination of two factors. First, wild rats probably were more resistant to cold than white rats. Second, winter conditions may be less severe than cold conditions imposed on animals kept individually in a cold chamber.

After the just mentioned work, the changes in the gut size in relation to animal age, sex and reproductive state were evaluated in Clethrionomys glareolus (Myrcha 1964, 1965) and Apodemus flavicollis (Gebczynska \& Gebczynski 1971). Taking them together, the main results of these studies were: (i) the digestive tract mass increases with body mass, but the ratio between both variables decreases with body mass; this result could be related with the decrease in relative metabolic demand with body size, (ii) seasonal change in gut size occurs, and is probably related more with the variation in food quality than with food availability, (iii) gut size increases during pup nursing, but not during pregnancy, (iv) reproductive adjustments of females in gut size are periodical and reversible. Between these early studies and the "bloom" of papers developed during the 90's (see below), there are a couple of works which tried to relate latitudinal patterns of body mass and population cycles of voles with nutritional variables, like food habitat and gut morphology (Hansson 1985, Hansson \& Jaarola 1989). These works showed that animals of northern populations of $C$. glareolus and Microtus agrestis, that consumed food rich in cellulose and other undigestible materials, have greater gut size than southern populations. In addition, it was proposed that it would be advantageous for herbivorous animals living on high fiber diets (such as $M$. agrestis), to increase their digestive capacity in high density populations, whereas for mixed granivorous/folivorous animals (such as $C$. glareolus) it would be advantageous to be able to rapidly change digestive physiology according to food supply.

As was previously mentioned, the development of optimal digestion theory (Sibly 1981), and the recognition of rodents as an attractive model to study digestive flexibility, motivated a myriad of field studies on gut size adjustments during the last twenty years. These studies demonstrated that: (i) seasonal variations in gut size are common and are mainly related with seasonal changes in diet quality and (or) environmental temperature (e.g., Bozinovic et al. 1990, Virgl \& Messier 1992, Brokowska 1995, Derting \& Noakes III 1995, Campbell \& MacArthur 1998, del Valle \& Busch 2003, Derting \& Hornung 2003), (ii) however, in some species the change in gut mass is similar to that observed in body size (Zuercher et al. 1999), and in other species there is no clear pattern of seasonal variation (Hammond 1993, Voltura 1997), (iii) females exhibited greater gut size than males around the year, and this difference usually was more noticeable during the breeding season (Bozinovic et al. 1990, Norrie \& Millar 1990, Brokowska 1995, Schwaibold \& Pillay 2003), (iv) there are no clear trends in the relationship between food habitats and gut flexibility, where some results suggest that omnivorous are more flexible than herbivorous species (e.g., Brokowska 1995), but others not (e.g., Derting \& Noakes III 1995), (v) when populations of the same species were compared, it was found that differences in gut size exist and that they are mainly related with differences in diet composition (e.g., Corp et al. 1997, Sassi et al. 2007), (vi) hibernation clearly affects the size of the gut (e.g., Galluser et al. 1988), and the increase in small intestine fresh mass during the activity season can reach $259 \%$ in relation to the values observed during hibernation (Hume et al. 2002), (vii) studies in semienclosure conditions along an altitudinal gradient, demonstrate that digestive organs size can be affected by changes in both, ambient temperature and oxygen partial pressure (Hammond et al. 1999, 2001).

\section{Experimental studies on wild rodents}

Sibly's (1981) digestion model -and specifically his third prediction "animals consuming poorer diets should have larger 
digestive chambers, other things being equals"also stimulated the development of many experimental studies on gut flexibility, spreading the current knowledge from laboratory mice and rats to several wild species. For example, during the second half of the 80 's, gut size flexibility was demonstrated in four wild species (Microtus ochrogaster, Peromyscus maniculatus, Abrothrix andinus, and Arvicola terrestris). The experimental factors tested in these studies were diet quality (Woodall 1989), and diet quality plus environmental temperature (Gross et al. 1985, Green \& Millar 1987, Bozinovic et al. 1988). In general terms, it was concluded that both increased energy demands and lower diet quality determine a rise in gut mass and length, mainly at the level of the small intestine and the cecum.

From the beginning of the 1990's until the present, the number of studies on gut flexibility in wild rodent species showed an even more rapid growth. In a nutshell, the results of this research can be summarized as: (i) an increase in digestive organs size due to an increase in diet fiber content occurs in Thomomys bottae (Loeb et al. 1991), Microtus ochrogaster (Hammond \& Wunder 1991, Castle \& Wunder 1995, Young Owl \& Baltzi 1998), Clethrionomys glareolus and Microtus agrestis (Lee \& Houston 1993, 1995), Microtus pennsylvanicus (Young Owl \& Baltzi 1998), Microtus brandtii (= Lasiopodomys brandtii, Pei et al. 2001a, Song \& Wang 2006), Meriones unguiculatus (Pei et al. 2001b, Liu \& Wang 2007), and Akodon azarae (del Valle et al. 2006), (ii) an increase in digestive organs size due to a decreasing environmental temperature occurs in Microtus ochrogaster (Hammond \& Wunder 1991, Castle \& Wunder 1995, Hammond \& Wunder 1995), Peromyscus maniculatus (French \& Porter 1994, Koteja 1996, Hammond \& Kristan 2000), Dicrostonyx groenlandicus (Hammond \& Wunder 1995), Microtus pinetorum (Derting \& Austin 1998), Microtus brandtii (Song \& Wang 2006), Akodon azarae (del Valle et al. 2004) and Phyllotis darwini (Bacigalupe et al. 2004, Naya et al. 2005), (iii) an increase in digestive organ's size due to lactation occurs in Peromyscus maniculatus (Hammond \& Kristan 2000), Microtus pinetorum (Derting \& Austin 1998), and Octodon degus (Naya et al. 2008a), (iv) changes in gut size due to the interaction between temperature and parasitism were reported for Microtus ochrogaster (Raines 1989), between temperature and diet quality for Dicrostonyx groenlandicus (Nagy \& Negus 1993), and between fiber and tannins content in the diet for Octodon degus (Bozinovic et al. 1997), (v) no change in gut morphology due to diet quality were recorded in Arvicola terrestris (Lee \& Houston 1993) and Phyllotis darwini (Sabat \& Bozinovic 2000), to photoperiod in Microtus agrestis (Krol et al. 2005), and to a toxic substance (albicard) in Peromyscus maniculatus (French \& Porter 1994).

\section{GENERAL CONCLUSIONS AND FURTHER DIRECTIONS}

The major goal of this review was to evaluate altogether the evidence on gut size flexibility in rodents collected from the fields of physiology and ecology, in order to identify the major findings achieved in this area during the last century. In this sense, the analysis of published data allowed us to conclude that: (1) Gut size flexibility is a widespread physiological mechanism, occurring in laboratory and wild species, and under laboratory, semi-natural and natural conditions. Moreover, flexibility in rodents occurs in species with different food habits (e.g., from strictly herbivores to omnivores that mainly prey on invertebrates), body size (e.g., from 15-20 g to $6000 \mathrm{~g}$ ), and life history traits (e.g., Microtus pinetorum versus $M$. pennsylvanicus). (2) Laboratory mice and rats appear to qualitatively demonstrate the digestive flexibility capacity of wild species, but a quantification of this has not been done yet. In this sense, some authors have claimed that changes in the field are lower than those found in indoor conditions (e.g., Heroux 1961), while others have expressed an opposite point of view (e.g., Hammond 1993). Obviously, at the core of this discrepancy is how much different indoor conditions are from natural conditions, which in turn, depends on species attributes (e.g., microhabitat use, territoriality, seasonal behavioral and physiological adjustment) and experimental design (how animals are reared or if nesting is allowed). (3) In laboratory species the experimental factors 
that have been more investigated are diet quality, reproductive status, environmental temperature and fasting. There are many works on diet quality and temperature for wild species, but few studies evaluated reproductive status and no one evaluated changes during fasting. Related to this difference in the kind of factors evaluated, recent analyses showed that small intestine length flexibility differs between experimental factors in laboratory species but not in wild rodents (Naya et al. 2007, 2008b). (4) For wild rodent species, no differences in small intestine length flexibility between methodological approaches (experimental versus observational) nor between species feeding categories (omnivorous, herbivorous, insectivorous) has been identified (Naya et al. 2008b). (5) It appears that high energetic demands, such as those imposed by lower temperatures and reproduction are mainly coped with by change at the small intestine level (absorptive chamber), while changes in the amount of undigestible material in the diet are mainly coped with by change in the hindgut (fermentative chambers). However, for laboratory mice and rats it was shown that although changes in diet quality provoke greater adjustments in hindgut size than increased energy demands, there are no differences between both factors for the case of the small intestine (Naya et al. 2007). (6) Increments in gut length appear to be related with a need to augment food retention time (e.g., during diet dilution), while increases in gut mass appear to be related with the need of higher specific absorption (e.g., during increasing energy demands). This is in agreement with the fact that adjustments due to change in diet quality are similar for both small intestine mass and length, while adjustments due to change in energy demands are greater for small intestine mass than for length (Naya et al. 2007). (7) Some studies suggested that the qualities of an energetic demand rather than simply its presence or absence can affect the amount of digestive adjustments (Kristan \& Hammond 2004). In this context, there was a positive relationship between gut size changes and both the number of pups reared (Sigdestad \& Osborne 1972, Hammond \& Diamond 1994, Hammond et al. 1994, 1996a) and the amounts of undigested material in the diet (El-Harith et al. 1976, Goodlad \& Mathers 1990). (8) In spite of the impressive number of studies on changes in gut size in rodents, quantitative comparisons of the existing data are difficult (Derting \& Austin 1998). This is because disparity among experimental treatments and how they are reported (e.g., diet quality experiments), differences in the types of data collected (e.g., length, wet mass, dry mass, masses of digestive organs with or without contents), variations in the kinds of statistical parameters reported (e.g., absolute means, least-squared corrected means, median), and differences in the amount of data reported (e.g., total gut versus each organ separately, all the dataset or only the significant changes).

To end this review, I want to point out some further directions for the study of rodents gut flexibility: (1) despite the likely evolutionary importance of physiological variability across populations inhabiting different habitats, relative few studies comparing gut flexibility among populations has been conducted. (2) Many rodent populations show first order dynamics (i.e., saw-toothed oscillations), and consequently, are excellent models to study the effects of contrasting densities on gut size flexibility under natural conditions. (3) A recent study found a clear correlation between small intestine length flexibility and latitude, reinforcing the adaptative value of digestive flexibility (Naya et al. 2008b). In order to advance our understanding on gut flexibility evolution, more global-scale comparative studies of this kind are desirable. (4) Information about the effect of different fixation techniques on gut tissue is scarce; this kind of data could be very relevant since it could allow the use of animals stored in zoological collections, and thus, to answer long term questions on digestive flexibility. (5) According to theoretical predictions from scaling, gut size flexibility should decrease with increasing body mass (see introduction). This result has not empirically tested yet. (6) Adjustments in the digestive organs are just one kind of potential phenotypic adjustments to changing environmental conditions. Information on the interplay between gut flexibility and other energy saving mechanism (e.g., torpor) is still scarce. (7) More experiments analyzing simultaneously short and long-term responses of gut size 
adjustments are needed; this is especially relevant to reach a better understanding of the temporal dynamic of the digestive flexibility.

Gut size flexibility in rodents has been studied for more than a century, and consequently, many of the original questions have been already answered. However, as we can see, many others are awaiting to be explored.

\section{ACKNOWLEDGMENTS}

I would like to thank to Sabrina Pino for her patience and the tremendous support during the course of this study. During this time, Pancho Bozinovic, Lucho Ebensperger and Bill Karasov were always present to assist me. Thank you a lot! I also wish to thank Leonardo Bacigalupe, Pato Camus, Mauricio Canals, Marco A. Lardies, Ariovaldo Pereira de la Cruz Neto, Pablo Sabat, Claudio Veloso, and fellows and professors at the Departmento de Ecología (PUC, Chile) for their continuous encourage during the last five years. Ian Hume kindly helped me to clarify some ideas and Arley Camargo helped me with the edition of the manuscript. Funded by Comisión Nacional de Investigación Científica y Tecnológica, Chile (FONDECYT \# 3060046 and FONDAP 15010001 Program 1).

\section{LITERATURE CITED}

ABRAMSON M (1934) The effects of pregnancy on the organ weights of the albino rat. American Journal of Obstetrics and Gynecology 27: 492-503.

ADDIS T (1932) Hypertrophy of the gastro-intestinal tract and high residue diets. American Journal of Physiology 99: 417-423.

ADDIS T, LJ POO \& W LEW (1936) The quantities of protein lost by the various organs and tissues of the body during a fast. Journal of Biological Chemistry 115: $111-118$

AGRAWAL AA (2001) Phenotypic plasticity in the interactions and evolution of species. Science 294: 321-326

BACIGALUPE LD \& F BOZINOVIC (2002) Design, limitation and sustained metabolic rate: lessons from small mammals. Journal of Experimental Biology 205: 2963-2970.

BACIGALUPE LD, RF NESPOLO, JC OPAZO \& F BOZINOVIC (2004) Phenotypic flexibility in a novel thermal environment: phylogenetic inertia in thermogenic capacity and evolutionary adaptation in organ size. Physiological and Biochemical Zoology 77: 805-815
BARNETT SA \& EM WIDDOWSON (1965) Organweights and body-composition in mice bred for many generations at $-3{ }^{\circ} \mathrm{C}$. Proceedings of the Royal Society of London 162B: 502-516.

BARNETT SA \& EM WIDDOWSON (1971) Organ weight and body composition of parturient and lactating mice, and their young, at $21^{\circ} \mathrm{C}$ and $-3{ }^{\circ} \mathrm{C}$. Journal of Reproduction and Fertility 26: 39-57.

BOOTH CC, KT EVANS \& DF STREET (1959) Intestinal hypertrophy following partial resection of the small bowel in the rat. British Journal of Surgery 46: 403410 .

BOZINOVIC F, C VELOSO \& M ROSENMANN (1988) Cambios del tracto digestivo de Abrothrix andinus (Cricetidae): efecto de la calidad de dieta y requerimientos de energía. Revista Chilena de Historia Natural 61: 245-251.

BOZINOVIC F, FF NOVOA \& C VELOSO (1990) Seasonal changes in energy expenditure and digestive tract of Abrothrix andinus (Cricetidae) in the Andes range. Physiological Zoology 63: 12161231.

BOZINOVIC F, FF NOVOA \& P SABAT (1997) Feeding and digesting fiber and tannins by the Herbivorous rodent, Octodon degus (Rodentia: Caviomorpha). Comparative Biochemistry and Physiology 118A: 625-630.

BROBECK JR, J TEPPERMAN \& CNH LONG (1943) Experimental hypothalamic hyperphagia in the albino rat. Yale Journal of Biological Medicine 15: 831-853.

BROKOWSKA A (1995) Seasonal changes in gut morphology of the striped field mouse (Apodemus agrarius). Canadian Journal of Zoology 73: 10951099.

BROWN OH, ML LEVINE \& M LIPKIN (1963) Inhibition of intestinal epithelial cell renewal and migration induced by starvation. American Journal of Physiology 205: 868-872.

BROWN RC, J KELLEHER \& MS LOSOWSKY (1979) The effect of pectin on the structure and function of the rat small intestine. British Journal of Nutrition 42: 357-365.

BURRIN DG, RA BRITTON \& CL FERRELL (1988) Visceral organ size and hepatocyte metabolic activity in fed and faster rats. Journal of Nutrition 118: 1547-1552.

CAMPBELL KL \& R MACARTHUR (1998) Nutrition and the energetic tactics of muskrats (Ondatra zibethicus): morphological and metabolic adjustments to seasonal shifts in diet quality. Canadian Journal of Zoology 76: 163-174.

CAMPBELL RM \& B FELL (1964) Gastrointestinal hypertrophy in the lactating rat and its relationship to food intake. Journal of Physiology (United Kingdom) 171: 90-98.

CANT JP, BW MCBRIDE \& WJ CROOM JR (1996) The regulation of intestinal metabolism and its impact on whole animal energetics. Journal of Animal Science 74: 2541-2553.

CAÑAS RJ, J ROMERO \& RL BALDWIN (1982) Maintenance energy requirements during lactation in rats. Journal of Nutrition 112: 1876-1880.

CAREY HV (1990) Seasonal changes in mucosal structure and function in ground squirrel intestine. American Journal of Physiology 259: 385-R392.

CAREY HV (1992) Effects of fasting and hibernation on ion secretion in ground squirrel intestine. American Journal of Physiology 263: 1202-1208.

CAREY HV \& HJ COOKE (1991) Effect of hibernation and 
jejunal bypass on mucosal structure and function. American Journal of Physiology 261: 37-44.

CAREY HV \& SL MARTIN (1996) Preservation of intestinal gene expression during hibernation. American Journal of Physiology 271: 805-813.

CASTLE KT \& BA WUNDER (1995) Limits to food intake and fiber utilization in the prairie vole, Microtus ochrogaster: effects of food quality and energy need. Journal of Comparative Physiology 164B: 609-617.

CONRAD ME, LR WEINTRAUB, B MERRILL \& WH CROSBY (1965) The effect of acetylphenylhydrazine upon epithelial turnover in the small intestine. American Journal of Digestive Diseases (New Series) 10: 43-46.

CORP N, ML GORMAN \& JP SPEAKMAN (1997) Apparent absorption efficiency and gut morphometry of wood mice, Apodemus sylvaticus, from two distinct population with different diet. Physiological Zoology 70: 610-614.

CRAFT IL (1970) The influence of pregnancy and lactation on the morphology and absorptive capacity of the rat small intestine. Clinical Science 38: 287-295

CRIPPS AW \& VJ WILLIAMS (1975) The effect of pregnancy and lactation on food intake, gastrointestinal anatomy and the absorptive capacity of the small intestine in the albino rat. British Journal of Nutrition 33: 17-32.

DEL VALLE JC \& C BUSCH (2003) Body composition and gut length of Akodon azarae (Muridae: Sigmontinae): relationship with energetic requirements. Acta Theriologica 48: 347-357.

DEL VALLE JC, AA LÓPEZ MAÑANES \& C BUSCH (2004) Phenotypic flexibility of digestive morphology and physiology of the South American omnivorous rodent Akodon azarae (Rodentia: Sigmodontinae). Comparative Biochemistry and Physiology 139A: 503-512.

DEL VALLE JC, C BUSCH \& AA LÓPEZ MAÑANES (2006) Phenotypic plasticity in response to low quality diet in the South American omnivorous rodent Akodon azarae (Rodentia: Sigmodontinae). Comparative Biochemistry and Physiology 145A: 397-405.

DEMMENT MW \& PJ VAN SOEST (1985). A nutritional explanation for body-size patterns of ruminant and nonruminant herbivores. American Naturalist 125: 641-672.

DERTING TL \& WH AUSTIN (1998) Changes in gut capacity with lactation and cold exposure in a species with low rates of energy use, the pine vole (Mircrotus pinetorum). Physiological Zoology 71: 611-623.

DERTING TL \& BA BOGUE (1993) Responses of the gut to moderate energy demands in a small herbivore (Microtus pennsylvanicus). Journal of Mammalogy 74: $59-68$.

DERTING TL \& C HORNUNG (2003) Energy demand, diet quality, and central processing organs in wild white-footed mice (Peromyscus leucopus). Journal of Mammalogy 84: 1381-1398.

DERTING TL \& EB NOAKES III (1995) Seasonal changes in gut capacity in the white-footed mouse (Peromyscus leucopus) and meadow vole (Microtus pennsylvanicus). Canadian Journal of Zoology 73 : 243-252.

DOWLING RH, EO RIECKEN, JW LAWS \& CC BOOTH (1967) The intestinal response to high bulk feeding in the rat. Clinical Science 32: 1-9.
DUDLEY S \& J SCHMITT (1996) Testing the adaptive plasticity hypothesis: density-dependent selection on manipulated stem length in Impatiens capensis. American Naturalist 147: 445-465.

DUNEL-ERB S, C CHEVALIER, P LAURENT, A BACH, F DECROCK \& Y LE MAHO (2001) Restoration of the jejunal mucosa in rats refed after prolonged fasting. Comparative and Biochemical Physiology 129A: 933-94.

EL-HARITH EA, JW DICKERSON \& R WALKER (1976) Potato starch and caecal hypertrophy in the rat. Food and Cosmetics Toxicology 14: 115-121.

ERSHOFF BH \& HJ DEUEL JR (1944) Inadequacy of lactose and beta-lactose as dietary carbohydrates for the rat. Journal of Nutrition 28: 225-234.

FABRY P \& V KUJALOVA (1960) Enhanced growth of the small intestine in rats as a result of adaptation to intermittent starvation. Acta Anatomica 43: 264271

FELL BF, KA SMITH \& RM CAMPBELL (1963) Hypertrophic and hyperplastic changes in the alimentary canal of the lactating rat. Journal of Pathology and Bacteriology 85: 179-188.

FISCHER JE (1957a) Effects of feeding diets containing lactose, agar, cellulose, raw potato starch or arabinose on the dry weights of cleaned gastrointestinal tract organs in the rat. American Journal of Physiology 188: 550-554.

FISCHER JE (1957b) Effects of feeding a diet containing lactose upon b-D-Galactosidase activity and organ development in the rat digestive tract. American Journal of Physiology 188: 49-53

FISCHER JE \& HW-T LEE(1958) Effects of feeding diets containing sucrose, cellobiose or glucose on the dry weights of cleaned gastrointestinal organs in the rats. American Journal Physiology 192: 417-420.

FISCHER JE \& HW-T LEE (1959) Possible associations of dietary residues with growth of the large gut. American Journal of Physiology 197: 903-911.

FOLEY WJ \& SJ CORK (1992) Use of fibrous diets by small herbivores - how far can the rules be "bent". Trends in Ecology and Evolution 7: 159-162.

FRENCH JB \& WP PORTER (1994) Energy acquisition and allocation in Peromyscus maniculatus exposed to aldicarb and cool temperatures. Environmental Toxicology and Chemistry 13: 927-933.

FRIEDMAN MHF (1953) The response of different regions of the gastrointestinal tract to normal and abnormal stimuli (influence of feeding inert bulk material and of hypophysectomy). Journal of National Cancer Institute 13: 1035-1038.

GALLUSER M, F RAUL \& B CANGUILHEM (1988) Adaptation of intestinal enzymes to seasonal and dietary changes in a hibernator: the European hamster (Cricetus cricetus). Journal of Comparative Physiology 158B: 143-149.

GEBCZYNSKA Z \& M GEBCYNSKI (1971) Length and weight of the alimentary tract of the root vole. Acta Theriologica 16: 359-369.

GOODLAD JS \& JC MATHERS (1990) Large bowel fermentation in rats given diets containing raw peas (Pisum sativum). British Journal of Nutrition 64: 569-587.

GOODLAD RA, JA PLUMB \& NA WRIGHT (1988) Epithelial cell proliferation and intestinal absorptive function during starvation and refeeding in the rat. Clinical Science (United Kingdom) 74: 301-306

GOODMAN MN \& A FLECK (1980) Starvation in the rat. I. Effect of age and obesity on organ weights, RNA, 
DNA and protein. American Journal of Physiology 239E: 269-276.

GREEN DA \& JS MILLAR (1987) Changes in gut dimensions and capacity of Peromyscus maniculatus relative to diet quality and energy needs. Canadian Journal of Zoology 65: 2159-2162.

GROSS JE, Z WANG \& BA WUNDER (1985) Effects of food quality and energy needs: changes in gut morphology and capacity of Microtus ochrogaster. Journal of Mammalogy 66: 661-667.

HAMMOND KA (1993) Seasonal changes in gut size of the wild prairie vole (Microtus ochrogaster). Canadian Journal of Zoology 71: 820-827.

HAMMOND KA \& J DIAMOND (1992) An experimental test for a ceiling on sustained metabolic rate in lactating mice. Physiological Zoology 65: 952-977.

HAMMOND KA \& J DIAMOND (1994) Limits to dietary nutrient intake and intestinal nutrient uptake in lactating mice. Physiological Zoology 67: 282-303.

HAMMOND KA \& DM KRISTAN (2000) Responses to lactation and cold exposure by deer mice (Peromyscus maniculatus). Physiological Biochemical Zoology 73: 547-556.

HAMMOND KA \& BA WUNDER (1991) The role of diet quality and energy need in the nutritional ecology of a small herbivore, Microtus ochrogaster. Physiological Zoology 64: 541-567

HAMMOND KA \& BA WUNDER (1995) Effect of cold temperatures on the morphology of gastrointestinal tracts of two microtine rodents. Journal of Mammalogy 76: 232-239.

HAMMOND KA, M KONARZEWSKI, R TORRES \& J DIAMOND (1994) Metabolic ceiling under a combination of peak energy demands. Physiological Zoology 68: 1479-1506.

HAMMOND KA, KCK LLOYD \& J DIAMOND (1996a) Is mammary output capacity limiting to lactational performance in mice? Journal of Experimental Biology 199: 337-349

HAMMOND KA, M LAM, KCK LLOYD \& J DIAMOND (1996b) Simultaneous manipulation of intestinal capacities and nutrient loads in mice. American Journal of Physiology 271G: 969-979.

HAMMOND KA, J ROTH, DN JANES \& MR DOHM (1999) Morphological and physiological responses to altitude in deer mice Peromyscus maniculatus. Physiological and Biochemical Zoology 72: 613622.

HAMMOND KA, J SZEWCZAK \& E KROL (2001) Effect of altitude and temperature on organ phenotypic plasticity along an altitudinal gradient. Journal of Experimental Biology 204: 1991-2000

HANSEN I, KE BACH KNUDSEN \& BO EGGUM (1992) Gastrointestinal implications in the rat of wheat bran, oat bran and ea fibre. British Journal of Nutrition 68: 451-462.

HANSSON L (1985) Geographic differences in bank voles Clethrionomys glareolus in relation to ecogeographical rules and possible demographic and nutritive strategies. Annales Zoologici Fennici 22: 319-328.

HANSSON L \& M JAAROLA (1989) Body size related to cyclicity in microtines: dominance behaviour or digestive efficiency? Oikos 55: 396-364.

HEROUX O (1961) Seasonal adjustments in captured wild Norway rats. I. Organ weights, ear vascularization, and histology of epidermis. Canadian Journal of Biochemistry and Physiology 39: 1865-70

HEROUX O \& JS CAMPBELL (1959) Comparison between seasonal and thermal acclimation in white rats. IV. Morphological and pathological changes. Canadian Journal of Biochemistry and Physiology 37: $1263-1269$

HEROUX O \& T GRIDGEMAN (1958) The effect of cold acclimation on the size of organs and tissues of the rat, with special reference to modes of expression of results. Canadian Journal of Biochemistry and Physiology 36: 209-216.

HILL RB, J PROSPER, JS HIRSCHFIELD \& F KERN JR (1968) Protein starvation and the small intestine. I. The growth and morphology of the small intestine in weanling rats. Experimental and Molecular Pathology 8: 66-74.

HOLECKOVA E (1964) Reaction to cold of rats adapted to intermittent feeding and fasting. Physiologia Bohemoslovaca 13: 78-80

HOLECKOVA E \& P FABRY (1959) Hyperphagia and gastric hypertrophy in rats adapted to intermittent starvation. British Journal of Nutrition 13: 260-266.

HUME ID (1989) Optimal digestive strategies in mammalian herbivore. Physiological Zoology 62: 1145-1163.

HUME ID, C BEIGLBOCK, T RUF, F FREY-ROOS, U BRUNS \& W ARNOLD (2002) Seasonal changes in morphology and function of the gastrointestinal tract of free-living alpine marmots (Marmota marmota). Journal of Comparative Physiology 172B: 197-207.

IKEGAMI S, F TSUCHIHASHI, H HARADA, N TSUCHIHASHI, E NISHIDE \& S INNAMI (1990) Effect of viscous indigestible polysaccharides on pancreatic-biliary secretion and digestive organs. Journal of Nutrition 120: 353-360.

JACKSON CM (1915) Effect of acute and chronic inanition upon the relative weights of the various organs and systems of adult albino rats. American Journal of Anatomy 18: 75-116.

JERVIS EL \& RJ LEVIN (1966) Anatomic adaptation of the alimentary tract of the rat to the hyperphagia of chronic alloxan-diabetes. Nature 210: 391-393.

JOHNSON IT \& JM GEE (1986) Gastrointestinal adaptation in response to soluble non-available polysaccharides in the rat. British Journal of Nutrition 55: 497-505.

JU JS \& ES NASSET (1959) Changes in total nitrogen content of some abdominal viscera in fasting and realimentation. Journal of Nutrition 68: 633-645.

JUSTICE KE \& FA SMITH (1992) A model of dietary fiber utilization by small mammalian herbivores, with empirical results for Neotoma. American Naturalist 139: 398-416.

KARASOV WH (1990) Digestion in birds: chemical and physiological determinants and ecological implications. In: Morrison ML, Ralph CJ, Verner J \& JR Jehl (eds) Avian foraging: theory, methodology, and applications: 391-415. Studies in Avian Biology Number 13, Cooper Ornithological Society, Lawrence, Kansas, USA.

KARASOV WH \& JM DIAMOND (1983) Adaptive regulation of sugar and amino acid transport by vertebrate intestine. American Journal of Physiology 245G: 443-462.

KARASOV WH \& SR MC WILLIAMS (2005) Digestive constraints in mammalian and avian ecology. In: Starck JM \& $\mathrm{T}$ Wang (eds) Physiological and ecological adaptations to feeding in vertebrates: 87112. Science Publishers, Enfield, New Hampshire, USA.

KESTNER O (1929) Nahrung und darmentwicklung. Pfluger's Archives 222: 662-669. 
KONARZEWSKI M \& J DIAMOND (1994) Peak sustained metabolic rate and its individual variation in cold-stressed mice. Physiological Zoology 67: 1186-1212.

KOTEJA P (1996) Limits to the energy budget in a rodent, Peromyscus maniculatus: does gut capacity set the limit? Physiological Zoology 69: 994-1020.

KRISTAN DM (2002) Effects of intestinal nematods during lactation: consequences for host morphology, physiology and offspring mass. Journal of Experimental Biology 205: 3955-3965.

KRISTAN DM \& KA HAMMOND (2000) Combined effects of cold exposure and sub-lethal intestinal parasites on host morphology and physiology. Journal of Experimental Biology 203: 3495-3504.

KRISTAN DM \& KA HAMMOND (2001) Parasite infection and caloric restriction induce physiological and morphological plasticity. American Journal of Physiology 281R: 502-510.

KRISTAN DM \& KA HAMMOND (2003) Physiological and morphological response to simultaneous cold exposure and parasite infection by wild-derived house mouse. Functional Ecology 17: 464-471.

KRISTAN DM \& KA HAMMOND (2004) Morphological plasticity varies with duration of infection: evidence from lactating and virgin wild-derived house mice (Mus musculus) infected with an intestinal parasite (Heligmosomoides polygyrus). Journal of Experimental Biology 207: 2351-2360.

KRISRTAN DM \& KA HAMMOND (2006) Effects of three simultaneous demands on glucose transport, resting metabolism and morphology of laboratory mice. Journal of Comparative Physiology 176B: 139-151.

KROL E, MS JOHNSON \& JR SPEAKMAN (2003) Limits to sustained energy intake. VIII. Resting metabolic rate and organ morphology of laboratory mice lactating at thermoneutrality. Journal of Experimental Biology 206: 4283-4291.

KROL E, P REDMAN, PJ THOMSON, R WILLIAMS, C MAYER, JG MERCER \& JR SPEAKMAN (2005) Effect of photoperiod on body mass, food intake and body composition in the field vole, Microtus agrestis. Journal of Experimental Biology 208: 571584.

LAWRENCE JV, JE FISCHER, TS SUTTON \& HH WEISER (1956) Adaptation of the rat to a high lactose diet: effect of the size of the cecum. Ohio Journal of Science (USA) 56: 87-92.

LEBLOND CP \& R CARRIERE (1955) The effect of growth hormone and thyroxine on the mitotic rate of the intestinal mucosa of the rat. Endocrinology 56: 261-266.

LEE HW-T \& JE FISCHER (1958) Effect of oral chlortetracycline on diarrhea and on the dry weights of cleaned intestinal organs in rats fed two different diets. American Journal of Physiology 192: 421-426.

LEE WB \& DC HOUSTON (1993) The effect of diet quality on gut anatomy in British voles. Journal of Comparative Physiology 163B: 337-339.

LEE WB \& DC HOUSTON (1995) The rate of change of gut anatomy in voles in relation to diet quality. Journal of Zoology London 236: 341-345.

LEVIN RJ \& DH SMITH (1963) The effect of the thyroid gland on intestinal absorption of hexoses. Journal of Physiology 169: 755-769.

LEVINE GM, JJ DEREN, E STEIGER \& R ZINNO (1974) Role of oral intake in maintenance of gut mass and disaccharide activity. Gastroenterology 67: 975982
LEVRAT, M-A, SR BEHR, C REMESY \& C DEMIGNE (1991) Effects of soybean fiber on cecal digestion in rats previously adapted to a fiber-free diet. Journal of Nutrition 121: 672-678.

LIU Q-S \& D-H WANG (2007) Effect of diet quality on phenotypic flexibility of organ size and digestive function in Mongolian gerbils (Meriones unguiculatus). Journal of Comparative Physiology 177B: 509-518.

LOEB SC, RG SCHWAB \& MW DEMMENT (1991) Responses of pocket ghophers (Thomomys bottae) to changes in diet quality. Oecologia 86: 542-551.

LOESCHKE K, E UHLICH \& R HALBACH (1973) Cecal enlargement combined with sodium transport stimulation in rats fed polyethylene glycol. Proceedings of the Society for Experimental Biology and Medicine 142: 96.

MAINOYA JR (1978) Possible influence of prolactin on intestinal hypertrophy in pregnant and lactating rats. Cellular and Molecular Life Science 34: 12301231.

MCBRIDE BW \& JM KELLY (1990) Energy cost of absorption and metabolism in the ruminant gastrointestinal tract and liver: a review. Journal of Animal Science 68: 2997-3010.

MCDEVIT RM \& JR SPEAKMAN (1994) Central limits to sustainable metabolic rate have no role in a cold acclimation of the short-tailed field vole (Microtus agrestis). Physiological Zoology 67: 1117-1139.

MCNURLAN MA, AM TOMKINS \& PJ GARLICK (1979) The effect of starvation on the rate of protein synthesis in rat liver and small intestine. Biochemical Journal 178: 373-379.

MCWILLIAMS SR \& WH KARASOV (2001) Phenotypic flexibility in digestive system structure and function in migratory birds and its ecological significance. Comparative Biochemistry and Physiology 128A: 579-593

MORGAN TB \& J YUDKIN (1957) The vitamin-sparing action of sorbitol. Nature 180: 543-545.

MUSACCHIA XJ \& RE BARR (1969) Cold exposure and intestinal absorption in the hamster. Federation Proceedings 28: 969-973.

MYRCHA A (1964) Variation in the length and weight of the alimentary tract of Clethrionomys glareolus. Acta Theriologica 9: 139-148

MYRCHA A (1965) Length and Weight of the alimentary tract of Apodemus flavicolis. Acta Theriologica 16: 225-228

NAGY TR \& NC NEGUS (1993) Energy acquisition and allocation in male collared lemmings (Dicrostonyx groenlandicus): effects of photoperiod, temperature, and diet quality. Physiological Zoology 66: 537-560.

NAYA DE \& F BOZINOVIC (2004) Digestive phenotypic flexibility in post-metamorphic amphibians: studies on a model organism. Biological Research 37: 365 370.

NAYA DE, LD BACIGALUPE, DM BUSTAMANTE \& F BOZINOVIC (2005) Dynamic digestive strategies in response to increased energy demands: a study in the leaf-eared mouse. Journal of Comparative Physiology 175B: 31-36.

NAYA DE, WH KARASOV \& F BOZINOVIC (2007) Phenotypic plasticity in laboratory mice and rats: a meta-analysis of current ideas on gut size flexibility. Evolutionary Ecology Research 9: 13631374

NAYA DE, LA EBENSPERGER, P SABAT \& F BOZINOVIC (2008a) Digestive and metabolic 
flexibility allows female degus to cope with lactation costs. Physiological and Biochemical Zoology 81: 186-194.

NAYA DE, F BOZINOVIC \& WH KARASOV (2008b) Latitudinal trends in physiological flexibility: testing the climatic variability hypothesis with data on the intestinal length of rodents. American Naturalist 172: E122-E134.

NORRIE MB \& JS MILLAR (1990) Food resources and reproduction in four microtine rodents. Canadian Journal of Zoology 68: 641-650.

PEI Y-X, DH WANG \& ID HUME (2001a) Selective digesta retention and coprophagy in Brandt's vole (Microtus brandtii). Journal of Comparative Physiology 171B: 457-464.

PEI Y-X, WANG D-H \& ID HUME (2001b) Effects of dietary fibre on digesta passage, nutrient digestibility, and gastrointestinal tract morphology in the granivorous Mongolian gerbil (Meriones ochrogaster) Physiological and Biochemical Zoology 74: 742-749.

PENRY DL \& PA JUMARS (1987) Modeling animal guts as chemical reactors. American Naturalist 129: 6996.

PETERS JM, CJ KRIJNEN \& EM BOYD (1967) Role of concepta in the production of hypertrophy and hydration of maternal body organs in the third week of pregnancy in albino rats. Journal of Reproduction and Fertility 14: 235-242.

PIERSMA T \& J DRENT (2003) Phenotypic flexibility and the evolution of organismal design. Trends in Ecology and Evolution 18: 228-233.

PIERSMA T \& A LINDSTROM (1997) Rapid reversible changes in organ size as a component of adaptive behaviour. Trends in Ecology and Evolution 12: 134-138

PIGLIUCCI M \& J SCHMITT (1999) Genes affecting phenotypic plasticity in Arabidopsis: pleiotropic effects and reproductive fitness of photomorphogenic mutants. Journal of Evolutionary Biology 12: 551-562.

POKSAY KS \& BO SCHNEEMAN (1983) Pancreatic and intestinal response to dietary starches and sugars in the rat. Journal of Nutrition 113: 1544-1549.

POO LJ, W LEW \& T ADDIS (1939) Protein anabolism of organs and tissues during pregnancy and lactation. Journal of Biological Chemistry 128: 69-77.

RAINES KM (1989) Effects of temperature and infection with Eimeria ochrogasteri on digestive organs of the prairie vole, Microtus ochrogaster. Journal of Parasitology 75: 601-605.

SABAT P \& F BOZINOVIC (2000) Digestive plasticity and the cost of acclimation to dietary chemistry in the omnivorous leaf-eared mouse Phyllotis darwini. Journal of Comparative Physiology 170B: 411-417.

SAKATA T (1987) Stimulatory effect of short-chain fatty acids on epithelial cell proliferation in the rat intestine: a possible explanation for trophic effects of fermentable fibre, gut microbes and luminal trophic factors. British Journal of Nutrition 58: 95 103.

SASSI PL, CE BORGHI \& F BOZINOVIC (2007) Spatial and seasonal plasticity in digestive morphology of cavies (Microcavia australis) inhabiting habitats with different plant qualities. Journal of Mammalogy 88: 165-172.

SCHEINER SM (1993) Genetics and evolution of phenotypic plasticity. Annual Review of Ecology and Systematics 24: 35-68.

SCHEINER SM (2002) Selection experiments and the study of phenotypic plasticity. Journal of Evolutionary Biology 15: 889-898

SCHEINER SM \& RF LYMAN (1991) The genetics of phenotypic plasticity. II. Response to selection. Journal of Evolutionary Biology 4: 23-50.

SCHMITT J, SA DUDLEY \& M PIGLIUCCI (1999) Manipulative approaches to testing adaptive plasticity: phytochrome-mediated shade-avoidance responses in plants. American Naturalist 154: 43-54.

SCHWAIBOLD U \& N PILLAY (2003) The gut morphology of the African ice rat, Otomys sloggetti robertsi, shows adaptations to cold environments and sex-specific seasonal variation. Journal of Comparative Physiology 173B: 653-659.

SECOR SM (2001) Regulation of digestive performance: a proposed adaptive response. Comparative Biochemistry and Physiology 128A: 565-577.

SIBLY RM (1981) Strategies of digestion and defecation. In: Towsend CR \& P Calow (eds) Physiological ecology: an evolutionary approach to resource use: 109-139. Blackwell Scientific Publications, Oxford, United Kingdom.

SIGESTAD CP \& JW OSBORNE (1972) Compensatory response of the intestine to lactation: the effect of irradiation. Growth 36: 165-171.

SONG Z-G \& D-H WANG (2006) Basal metabolic rate and organ size in Brandt's voles (Lasiopodomys brandtii): effects of photoperiod, temperature and diet quality. Physiology and Behavior 89: 704-710.

SOUDERS HJ \& AF MORGAN (1957) Weight and composition of organs during the reproductive cycle in the rat. American Journal of Physiology 191: 1-7.

SPEAKMAN JR \& E KROL (2005) Limits to sustained energy intake IX: a review of hypotheses. Journal of Comparative Physiology 175B: 375-394.

SPEAKMAN JR \& J MCQUEENIE (1996) Limits to sustained metabolic rate: the link between food intake, basal metabolic rate, and morphology in reproducing mice, Mus musculus. Physiological Zoology 69: 746-769.

SPICER JI \& KJ GASTON (1999) Physiological diversity and its ecological implications. Blackwell Science, Oxford, United Kingdom. 241 pp.

STALINSKI J (1994) Digestive responses to cold in yellow-necked mouse. Polish Ecological Studies 20: 443-448

STARCK JM (1999) Structural flexibility of the gastrointestinal tract of vertebrates - Implications for evolutionary morphology. Zoologischer Anzeiger 238: $87-101$.

STEINER M, HR BOURGIS, LS FREEDMAN \& SL GRAY (1968) Effect of starvation on the tissue composition of the small intestine of the rat. American Journal of Physiology 215: 74-77.

THAYSEN EH \& JH THAYSEN (1949) Morphological change in the gastrointestinal tract of the white rat following inanition. Acta Pathologica 26: 370-379.

TOLOZA E, M LAM \& J DIAMOND (1991) Nutrient extraction by cold-exposed mice: a test of digestive safety margins. American Journal Physiology 261G: 608-620.

TOKUNAGA T, T OKU \& N HOSOYA (1986) Influence of chronic intake of new sweetener fructooligosaccharide (Neosugar) on growth and gastrointestinal function of the rat. Journal of Nutrition Science and Vitaminology 32: 111-121.

VIRGL JA \& F MESSIER (1992) Seasonal variation in body composition and morphology of adult muskrats in Central Saskatchewan, Canada. Journal of Zoology London 228: 461-477. 
VOLTURA MB (1997) Seasonal variation in body composition and gut capacity of the pariré vole (Microtus ochrogaster). Canadian Journal of Zoology 75: 1714-1719.

WANG T, CCY HUNG \& DJ RANDALL (2006) The comparative physiology of food deprivation: from feast to famine. Annual Review in Physiology 68: 223-251.

WIERDA JL (1942) Measurements and observations upon the intestine of rats fed unbalanced and supplemented diets. American Journal of Anatomy 70: 433-453

WIERDA JL (1950) A comparison of the weight of the intestine with the body and kidney weights in rats which were fed artificial unbalanced diets. Anatomical Records 107: 221-233.

WOODALL PF (1989) The effects of increased dietary cellulose on the anatomy, physiology and behaviour of the captive water voles, Arvicola terrestris (L.) (Rodentia: Microtinae). Comparative Biochemistry and Physiology 94A: 615-621.

WUNDER BA (1992) Morphophysiological indicators of

Associate Editor: Marco Lardies

Received April 1, 2008; accepted September 8, 2008 the energy state of small mammals. In: Tomasi TE \& TH Horton (eds) Mammalian energetics: 83-104. Comstock, Ithaca, New York, USA.

YOUNG OWL M \& GO BATZLI (1998) The integrated processing response of voles to fibre content of natural diets. Functional Ecology 12: 4-13.

ZHAO X-Q, H JORGENSEN, VM GARBET \& BO EGGUM (1995) The influence of dietary fibre on body composition, visceral organ weight, digestibility and energy balance in rats housed in different thermal environments. British Journal of Nutrition 73: 687-699.

ZHAO X-Q, H JORGENSEN, VM GABERT \& BO EGGUM (1996) Energy metabolism and protein balance in growing rats housed in $18{ }^{\circ} \mathrm{C}$ or $28{ }^{\circ} \mathrm{C}$ environments and fed different levels of dietary protein. Journal of Nutrition 126: 2036-2043.

ZUERCHER GL, DD ROBY \& EA RESTAD (1999) Seasonal changes in body mass, composition, and organs of northern red-backed voles in interior Alaska. Journal of Mammalogy 80: 443-459. 